\title{
The oldest aphid insect from the Middle Triassic of the Vosges, France
}

Jacek Szwedo and André Nel

Acta Palaeontologica Polonica 56 (4), 2011: 757-766 doi: http://dx.doi.org/10.4202/app.2010.0034

A new family Vosegidae is described for Vosegus triassicus gen. et sp. nov. from the Anisian (early Middle Triassic)

Grès à Voltzia Formation of the Vosges (north-eastern France). This is the oldest Aphidomorpha presenting the combination of characters as: elongate and tapered pterostigma with straight posterior margin, thick common stem of veins $\mathrm{Sc}+\mathrm{R}+(\mathrm{M})+\mathrm{CuA}$, arcuate $\mathrm{RP}$ separated well basad of pterostigma base, three-branched $\mathrm{M}$ with free base, $\mathrm{CuA}$ forked, veins not differentiated in their thickness. The morphological characters presented by Vosegus are spread among the different extinct and extant lineages of Aphidomorpha, but the combination presented is unique. The relationships of this new family to other Triassic Sternorrhyncha are discussed, concluding its placement in Aphidomorpha: Triassoaphidoidea. The specificity of Grès à Voltzia fossil site in respect to early evolution of aphids is presented, with two competing explanations for size diminution, considering the Early Triassic biotic recovery versus the correlation between early aphid diversification and the exploitation of new niches, new host plants and habitats. This new finding increases the taxonomic diversity of the Grès à Voltzia fauna, expanding our knowledge of Early Triassic Aphidomorpha diversity and evolution.

Key words: Aphidomorpha, fossil aphid, phylogeny, Triassic, Anisian, Vosges, France.

Jacek Szwedo [szwedo@miiz.waw.pl], Museum and Institute of Zoology, Polish Academy of Sciences, 64, Wilcza Street, PL 00-679 Warszawa, Poland; André Nel [anel@mnhn.fr], CNRS UMR 7205, CP 50, Entomologie, Muséum national d'Histoire naturelle, 45, rue Buffon, F-75005 Paris, France.

This is an open-access article distributed under the terms of the Creative Commons Attribution License (for details please see creativecommons.org), which permits unrestricted use, distribution, and reproduction in any medium, provided the original author and source are credited. 
FoF Full text $(481.9 \mathrm{kB})$ 